\title{
Combination of Photovoltaic (PV) with a Transparent Glass to Estimate Sea Water to be Fresh
}

\author{
Duma Pabiban, Mikael Namas, Indranata Panggalo, Johanes W. D. Therik \\ \{dumapabiban@gmail.com, kk.mikaelnamas18@gmail.com, indrapanggalo@gmail.com, \\ hendromeda@gmail.com \} \\ Politeknik Negeri Kupang
}

\begin{abstract}
Solar energy available throughout the day should be used for processing sea water into fresh water through the application of solar distillation technology. This technology is applied to the people of Indonesia who live on the coast because of lack of clean water for drinking and bathing water and other needs in accordance with their designation. The objectives of this study are: 1) to determine the productivity of solar distillation devices of the type of solar panels by combining transparent glass to produce fresh water. The research method used in this study is the experimental method and action. This research was conducted at the Kupang State Polytechnic Physics Laboratory, Adisucipto Penfui Road, East Nusa Tenggara Province. Materials and tools used in conducting research are: 1) solar panels; 2) inverter; 3) Battery; 4) heater; 5) transparent glass; 6) measuring cup; 7) sea water samples. The results of the study resulted in an average value produced by the design of a combination of solar panels with transparent glass every day is $128 \mathrm{ml} /$ day, the time required is approximately 3 hours for the evaporation process and the average temperature produced is $890 \mathrm{C}$. Target output of this study is producing fresh water. The results of this research will be disseminated to the scientific community through publications and seminars.
\end{abstract}

Keywords: Distillation, solar panels, transparent glass, sea water

\section{Introduction}

Water is a very important requirement for living things. For humans, the need for clean water is a need that cannot be separated because it is widely used in every activity of daily life, such as cooking, washing, bathing and other needs. The crisis of fresh water for drinking water is generally experienced by the majority of people who live on the coast because there is no supply of fresh water sourced from the local PDAM. Most of the water on this planet is salt water so it cannot be used directly for drinking water [1].

The availability of clean water is a step product and is a major problem in coastal areas, supporting the availability of clean water in urban coastal areas such as Kupang city by consuming water from wells, PDAMs and reverse osmosis which are now mushrooming on the edges of roads. To get clean water to meet the necessities of life both for cooking, drinking water, washing, bathing the community must pay a large fee [2] 
Efforts that can be made to supply clean water are to utilize existing water sources, namely sea water which is so abundant and easily obtained at any time. But the sea water has a salty taste and has a high salt content. One alternative for the provision of clean water is to utilize existing water sources, namely using distillation technology by separating a material based on boiling point and utilizing thermal energy. Currently the source of heat energy that is widely used for the distillation process comes from electrical energy. But electricity is considered quite expensive, the solution is by developing environmental technology through solar power generation technology by utilizing the sun's rays as a source of electricity generation.

But the weakness of the sun's energy as an energy source to be used as a source of distillation is weather factors such as cloudy, rain, wind and how to focus the bolic on the focal plane (heating container), resulting in reduced distillate volume [3]. Although research has been carried out to produce distillation of sea water into fresh water, namely: Solar-type parabolic distillation system to reduce levels of sea water salinity [3]; Decellination of solar power based on solar power to produce fresh water [4]; Surface Radiation Absorber Surface Characteristics of Solar Still and Its Application as a Distillation Tool for Sea Water into Fresh Water [5]. But research needs to be done to get fresh water that is a combination of solar panels with transparent glass systems for freshwater productivity

Based on the description from this background, the problems in this research can be formulated: 1) how to design a solar panel mechanical system with transparent glass to produce fresh water as drinking water?; 2) how is the performance of the solar panel mechanical system with transparent glass to produce fresh water?

The objectives of this research are: 1) to design a combination of solar panels with transparent glass to distill sea water into fresh water; 2) determine the performance of a solar panel combination device with transparent glass to produce fresh water (distillate). The benefits of this research are: 1) making the product to distill sea water into fresh water by utilizing a solar panel combination system with transparent glass; 2) the product can be utilized for people who live around the coast by using sea water as fresh water.

\section{Literature Review}

\subsection{Photo Voltaic (PV)}

Photo Voltaic is a semi-conductor equipment that can convert solar energy into electrical energy. Photo poltaic is a panel consisting of several cells and various types. Photo poltaic is a slice of silicon material that has been processed in such a way that it has semi-conductor properties, there will be an electrical voltage between the back side contact with the front side contact when sunlight hits the photovoltaic surface. In general photo voltaic is a semi-conductor that can absorb particles or elements from sunlight and convert it into electrical energy. Sunlight that can be absorbed by photo voltaic ranges from $30 \%$ to $50 \%$ [6] 


\subsection{Salinity}

Salinity is defined as the amount of solid material contained in each kilograms of sea water, expressed in grams per kilogram or per thousand. Salinity is the percentage of kholorida elements contained in 1 kilogram of sea water. Salinity is the amount of weight of all salt (in grams) that is dissolved in 1 liter of water, usually expressed in units of rage per liter [7]

\subsection{Distillation}

According to Salvato in Hidayat [8] suggested that distillation is very useful for the conversion of sea water into fresh water. conversion of sea water into fresh water can be done by artificial heat distillation techniques, solar distillation, osmosis electrodialysis, gas hydration, freesing and others. Distillation can be interpreted as a process of liquid evaporation, cooling of the vapor produced and the collection of condensate in a place or container. The distillation method is very useful for separating a mixture consisting of components with a boiling point that is dissecting or one of the components cannot be evaporated [9]. This type of steam distillation is used as a mixture of compounds which have boiling points reaching $200 \mathrm{oC}$ or more. Steam distillation can evaporate these compounds by approaching $100 \mathrm{oC}$ under atmospheric pressure by using steam or boiling water [10].

\subsection{Solar energy}

Solar power is basically sunlight which is electromagnetic radiation at visible and invisible wavelengths that covers the spectrum of infrared light to ultraviolet light. Solar thermal energy is one of the potential energy to be managed and developed further as a source of energy reserves, especially for countries located in the equator including Indonesia, where the sun shines throughout the year. There are several ways of utilizing solar thermal energy, namely heating the room, lighting the room, drying agricultural products, distilling dirty water, heating water, and generating electricity [11].

\subsection{Evaporation System}

According to Lakitan [11] Evaporation rates in Indonesia occur in evaporation depending on the height of the place and time. In January to April the rate of evaporation is still low, the peak occurred in June to September. The evaporation process will be better if the temperature of sea water in the evaporation chamber is higher. The higher the temperature of a liquid, the faster the movement of molecules in it to occur between collisions between molecules that will cause the faster process of mass transfer from liquid to gas called evaporation.

\subsection{Battery (battery)}

Battery or battery is an electric cell in which a reversible electrochemical process takes place (can be reversed) with high efficiency. The reversible process is that in the battery the process of converting chemicals into electricity (emptying process), and vice versa from electric power to chemical power, replenishment by regeneration of the electrodes used is by passing an electric current in the opposite direction (polarity) in the cell. The amount of electric power stored in baerry that is used as a source of electricity depends on the capacity of the battery in the ampere hour $(\mathrm{AH})$ channel. If the box says $12 \mathrm{Volt} 60 \mathrm{AH}$ it means the battery has a 12 volt 
voltage where if the battery is used for 1 hour with a current of 60 amperes, the battery capacity after 1 hour will be empty (exhausted). The battery capacity is also empty after 2 hours if the current usage is only 30 amperes. Thus it can be concluded that the length of battery discharge is determined by the amount of electric current used from the battery. The greater the electric current from the battery the greater the current used, the faster the battery will empty and vice versa the smaller the current used the longer the battery will experience emptying. The amount of battery capacity is largely determined by the surface area of the plate or the number of battery plates. As the plate area increases or the number of battery plates increases, the battery capacity will also increase. Whereas the battery voltage is determined by the amount of the battery cell where a battery cell can usually produce a voltage of approximately 2 to 2.1 volts. The voltage generated is equal to the amount of the voltage in each cell. If the battery has 6 cells, then the standard battery voltage is 12 volts to 12.6 volts, [12].

\subsection{Solar Panel Regulator}

Solar panel regulator is a series of regulations or regulating the output voltage of a power so that the effect of the rise and fall of the grid voltage does not affect the voltage of the power supply so that it becomes stable. If the voltage from the PLN source goes up and down, the output voltage will also go up and down. If the current is greater, the output voltage will also go down. If this voltage change is disturbing enough, an active component is needed which can regulate the output voltage to be stable [13]

\subsection{Solar Charge Controller}

Solar Charge Controller is a device used to control the process of charging an electric charge from solar panels to a battery and also discharging an electric charge from a battery to a load such as lights, inverters, TVs, etc. There are at least two types of solar controllers, which use PWM (pulse width modulation) technology and MPPT (maximum power point tracking). The PWM solar charge controller will charge the electric charge to the battery with a large current when the battery is empty, and then the charging current is gradually reduced when the battery gets full. This technology allows the battery to be filled in a completely full condition without causing problems with the battery. When the battery is full the solar controller will keep the battery full with a certain float voltage.

To make the SHS circuit work, the output voltage of the solar panel must be greater than the battery voltage that will be charged with an electric charge. If the solar panel output voltage is the same or even less than the battery voltage, then the process of charging an electric charge to the battery will not occur. Generally solar panels can have an output voltage of around 18 volts, enter the solar controller which has an output voltage between $14.2-14.5$ volts for charging a 12 volt battery. Thus there will be an excess voltage around $(18-14.5=3.5)$ Volts. In solar controllers with MPPT (maxsimum power point tracking) technology, this excess voltage will be converted to an additional battery charging current, so this technology has a higher efficiency than PWM [14]. Calculation of Capacity for Battery Charge Regulators (BCR).

$\mathrm{I} \max =\mathrm{P} \max / \mathrm{Vs}$

I max: Current Capacity 
P max: Maximum load

Vs: Maximum voltage

The physical form of the solar charge controller can be seen in Figure 1.

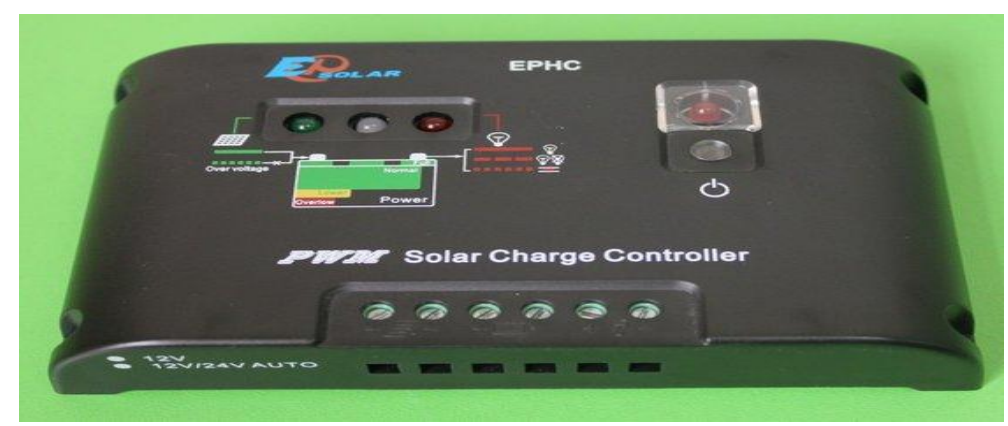

Figure 2.1 Solar Charge Controller [14]

\subsection{Battery}

The battery is a storage medium for electrical charges. Broadly speaking, batteries are distinguished by application and construction. Based on the application, the battery is distinguished for engine starter (automotive) and deep cycle. Automotive batteries are generally made with thin but large lead plates so that the surface area is larger (Figure 2.2). Thus this battery can supply a large electric current at the beginning to start the engine. Deep cycle batteries are usually used for photovoltaic systems (solar cells) and back up power, where the battery is capable of experiencing discharges so that the electrical charge is low [14]

Types of Starter and Deep Cycle Batteries can be seen in Figure 2.
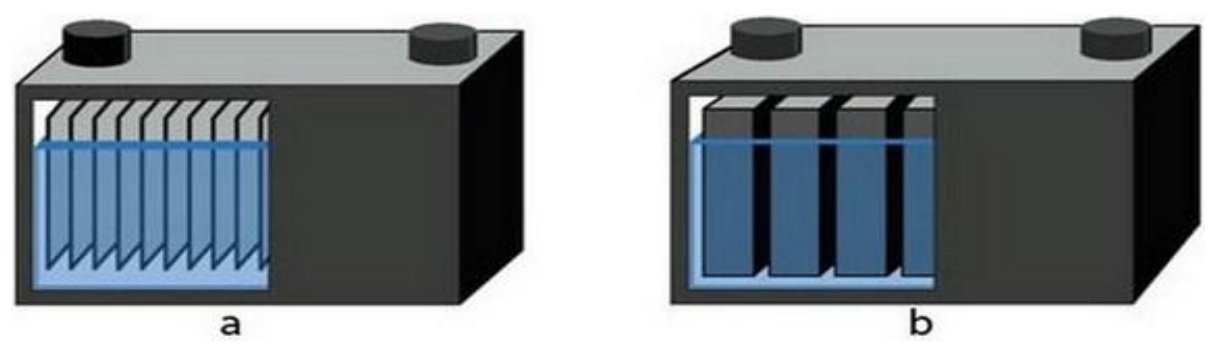

Figure 2. Types of Starter and Deep Cycle Batteries [14]

\subsection{Efficiency}

The efficiency of the volume of water produced, can be determined by the efficiency of water using 2 ways to compare it with the total amount of sea water with the amount of pure water contained in sea water. Efficiency can be formulated, namely [4]:

Efficiency $=($ Distillate volume $) /($ Input volume $) \mathrm{X} 100 \%$ 


\section{Research Methods}

\subsection{Type of Research}

This research is an action research and experimental research. In this study includes several stages, namely the tool design approach, the stage of making tools and the stage of testing tools and measuring the results of distillate (fresh water).

\subsection{Research location}

To carry out this research, it is located at the Kupang State Polytechnic Physics Laboratory, Adisucipto street Penfui Kodya Kupang, East Nusa Tenggara Province.

\subsection{Research Time}

This research activity lasted for 6 months. The implementation of this research consisted of 2 stages, namely: the preparatory stage included: inventory of materials and equipment; design of making distillation equipment (mechanical work); The implementation phase includes: tool assembly; test tool; sea water sampling; measurement of sea water distillation results; data analysis and reporting and publication.

3.4 Research Step (Research Road Map)

The complete research flow is shown in Figure 3.

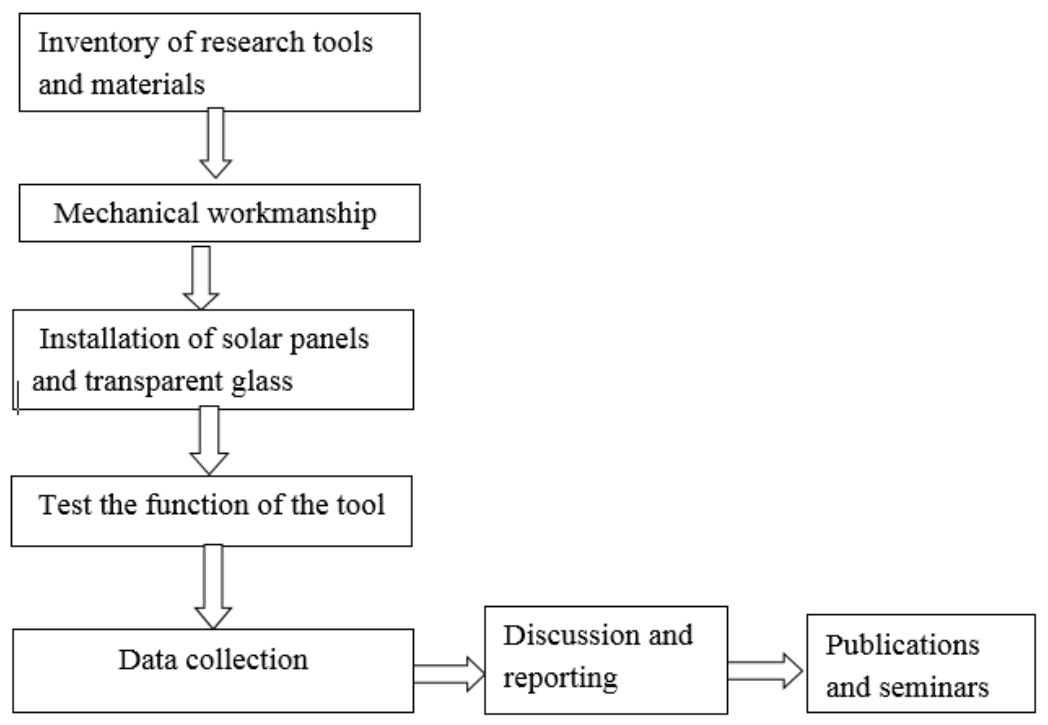

Figure 3. Research flow chart 


\subsection{Research Materials}

Materials and research tools used in the process of carrying out research activities consist of: 1) photo poltaic; 2) transparency glass; 3) inverter; 4) alumium plate; 4) jumper cable; 5) glass cleaning; 6) seawater samples; 7) measuring cup; 8) iron frame; 9) Iron bolts; 10) seawater storage tanks; 11) iron pipe; 12) paralon pipes; 13) heating element; 14) digital thermometer; 15) actinograph; 16) battery; 17) HIS cable

\subsection{Types and sources of data}

The type of data in this study consisted of primary data and secondary data. Primary data is data directly obtained from the study site in the form of data from the measurement of distillation of sea water into fresh water. Secondary data is data that is stored and documented and data derived from previous studies such as journals and previous research results.

\subsection{Data Analysis Techniques}

Data analysis techniques in this study consisted of:

1. Measuring the results of distillate (volume of fresh water) for 3 times the treatment, the first treatment is $1000 \mathrm{ml} ; 1500 \mathrm{ml}$ and $2000 \mathrm{ml}$.

2. Measuring the intensity of daylight

3. Measuring the temperature in the sea water storage room

4. Data processing and discussion

5. Conclusions

\section{Results and Discussion}

\subsection{Research Results}

a. Mechanical Work of Combination of Photo Voltaic (PV) with Transparent Glass

The implementation of mechanical work begins with the welding of the iron profile frame as a base for seawater storage tanks. The frame is a place to support from the container and transparent glass. This iron frame is made of iron L. The size of the iron frame is $70 \mathrm{~cm}$ long; width of $70 \mathrm{~cm}$ and height of $85 \mathrm{~cm}$. The size of the water reservoir made of aluminum plate consists of a length of $53 \mathrm{~cm} ; 43 \mathrm{~cm}$ wide and $10 \mathrm{~cm}$ high. the specifications of the transparent glass frame at the top are $54 \mathrm{~cm}$ long, $44 \mathrm{~cm}$ wide, $0.5 \mathrm{~cm}$ thick glass.

b. Block diagram of a combination of solar panels (Photovoltaic) with transparent glass to produce fresh water.

A block diagram of a photovoltaic combination with transparent glass to produce fresh water can be seen in Figure 4. 


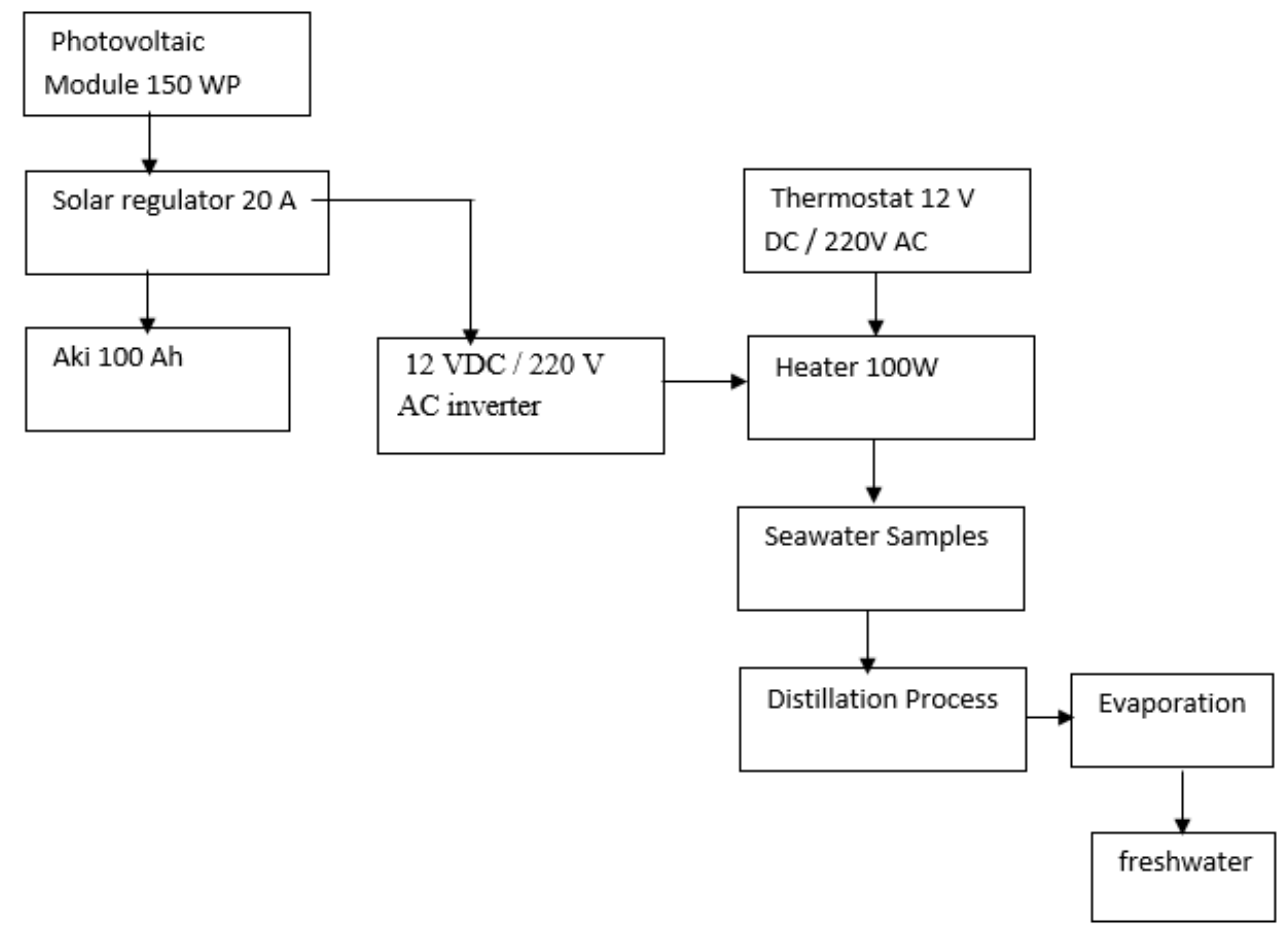

Figure 4. Block diagram of the process of distillation of sea water into fresh water

Based on Figure 4 explained that the photovoltaic (pv) module of sunlight energy absorbed is converted into electrical energy. The electricity that has been generated will move through the solar regulator to the place of storage, which is the battery or battery. After going through the solar regulator the DC electric current will be stored in the battery or the battery will be converted on the inverter into alternating AC electric voltage. AC alternating electric current is then channeled to the heater (heater) by conduction and convection in the sea water reservoirs. As a result of the occurrence of heating in seawater storage tanks, a distillation process occurs, namely the occurrence of evaporation accompanied by points of water on a transparent glass wall. The moisture vents will be channeled through the evaporation pipe to be accommodated in a storage container. The results of this distillation process will produce fresh water (distillate).

\section{c. Measurement Result Data}

The sample used in this study was a sample of sea water from the coast of Oesapa, the municipality of Kupang. In the research activity carried out 3 times, sea water samples start from a volume of $1000 \mathrm{ml} ; 1500 \mathrm{ml}$; and $2000 \mathrm{ml}$. The design of the instrument used is a combination of photovoltaic with transparent glass to produce fresh water.

During the research activities starting at 09.00 until 14.00 with a period of approximately 9 days. Data is collected by measuring the intensity of light with an actinograph measuring instrument; The temperature is measured by a digital thermometer and the results of the evaluation (distillate) using a measuring cup. The quantity of fresh water produced during the study with $1000 \mathrm{ml}$ treatment; $1500 \mathrm{ml}$ and $2000 \mathrm{ml}$ respectively can be seen in Table 1 . 
Table 1. Data from measurements of solar intensity, distillate results, temperature during July 2019.

\begin{tabular}{cccccc}
\hline No. & $\begin{array}{c}\text { Sea water } \\
\text { treatment } \\
(\mathrm{ml})\end{array}$ & $\begin{array}{c}\text { Distillation } \\
\text { results }(\mathrm{ml})\end{array}$ & $\begin{array}{c}\text { Intensity of } \\
\text { Sunlight } \\
\left(\mathrm{W} / \mathrm{M}^{2}\right.\end{array}$ & $\begin{array}{c}\text { Temperature } \\
\left({ }^{\circ} \mathrm{C}\right)\end{array}$ & $\begin{array}{l}\text { Evaporation } \\
\text { time }\end{array}$ \\
\hline 1. & 1000 & 96 & 680 & 85 & $11.00-13-00$ \\
2. & 1000 & 98 & 700 & 90 & $12.00-14.00$ \\
3. & 1000 & 99 & 720 & 90 & $12.00-14.00$ \\
4. & 1500 & 110 & 680 & 87 & $11.00-13.00$ \\
5. & 1500 & 115 & 700 & 90 & $11.00-13.00$ \\
6. & 1500 & 135 & 680 & 89 & $11.00-13.00$ \\
7. & 2000 & 260 & 730 & 90 & $12.00-14.00$ \\
8. & 2000 & 270 & 710 & 89 & $12.00-14.00$ \\
9. & 2000 & 265 & 700 & 90 & $11.00-13.00$ \\
\hline
\end{tabular}

Source: Primary Data, 2019

\subsection{Discussion}

To simplify the test and calculation data from Table 1 , it can be seen the average distillate results, the intensity of daylight and the temperature produced during the test can be shown in Table 2.

Table 2. Average distillation results, sunlight intensity, temperature and evaporation time

\begin{tabular}{|c|c|c|c|c|c|}
\hline No. & $\begin{array}{c}\text { Sea water } \\
\text { treatment } \\
(\mathrm{ml})\end{array}$ & $\begin{array}{c}\text { Distillation } \\
\text { results }(\mathrm{ml})\end{array}$ & $\begin{array}{c}\text { Intensity of } \\
\text { Sunlight } \\
\left(\mathrm{W}^{\prime} \mathrm{M}^{2}\right.\end{array}$ & $\begin{array}{c}\text { Temperature } \\
\left({ }^{\circ} \mathrm{C}\right)\end{array}$ & $\begin{array}{c}\text { Evaporation } \\
\text { time }\end{array}$ \\
\hline 1. & 1000 & 98 & 700 & 88 & $11.00-14-00$ \\
2. & 1500 & 120 & 687 & 88 & $11.00-13.00$ \\
3. & 2000 & 165 & 720 & 90 & $12.00-14.00$ \\
\hline
\end{tabular}

Data on the results of testing the productivity of tools resulting from a combination of solar panels with transparent glass to produce fresh water and daylight intensity can be shown in Figure 5 .

Based on Figure 5. it is known that the average value produced by the combination of solar panels (photo voltaic) with transparent glass at $1000 \mathrm{ml}$ treatment; $1500 \mathrm{ml}$ and $2000 \mathrm{ml}$ of seawater, respectively, are $98 \mathrm{ml}$ of fresh water; $120 \mathrm{ml}$ of fresh water and $165 \mathrm{ml}$ of fresh water. During the evaporation process, it takes approximately 3 hours, starting from 11.00 to 13.00 hours and 11.00 to 14.00 hours. the process of evaporation as well as an increase in the production of distillates (fresh water) is highly dependent on weather conditions, wind and the placement or position of the equipment used. , also the increase in freshwater production is also influenced by wind and weather when the research is ongoing, [3]. While the intensity of daylight obtained during the study in sequence at a treatment of $1000 \mathrm{ml} ; 1500 \mathrm{ml}$ and $2000 \mathrm{ml}$ are $700 \mathrm{w} / \mathrm{m}^{2} ; 687 \mathrm{w} / \mathrm{m}^{2}$; and $713 \mathrm{w} / \mathrm{m}^{2}$. The occurrence of differences in the value of daylight intensity because it is done on a different day. 


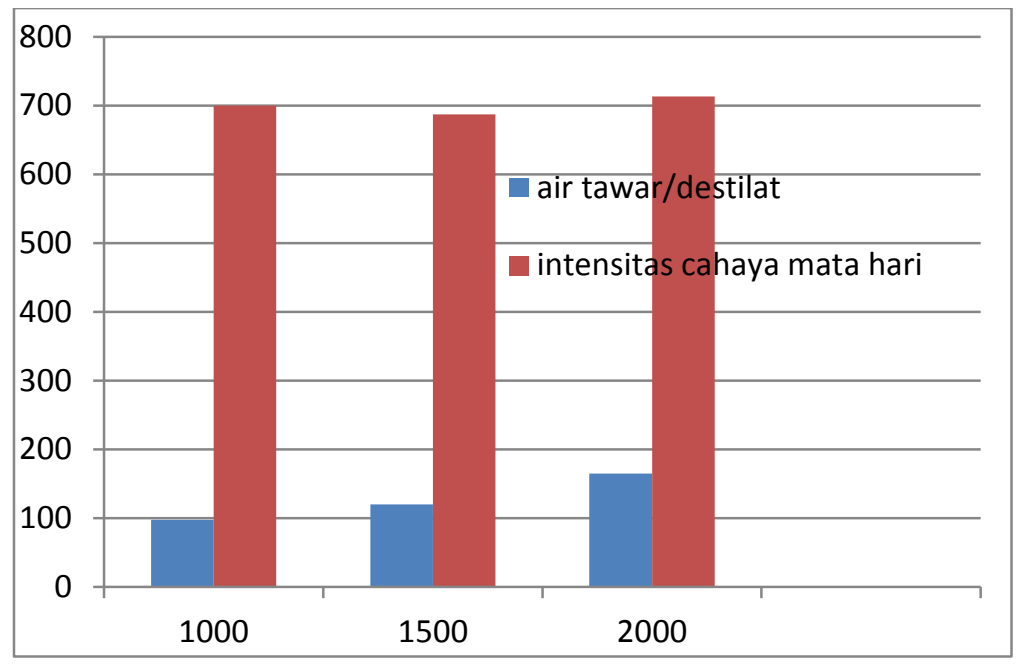

Figure 5. the results of productivity measurements produced by solar panels with transparent glass

Data on the results of testing the productivity of tools resulting from a combination of solar panels with transparent glass to produce fresh water and temperature can be shown in Figure 6 .

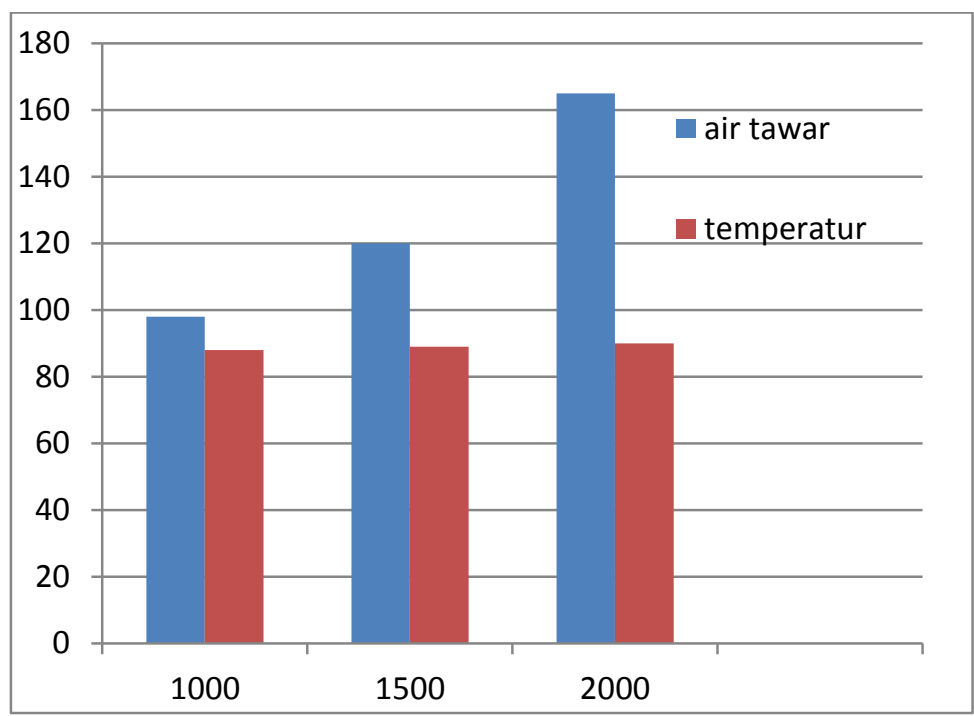

Figure 6. The average value of the measurement results of fresh water production and temperature during the test

Based on Figure 6 it is known that the average value of temperature produced by a combination of solar panels (photo voltaic) with transparent glass at $1000 \mathrm{ml}$ treatment; 1500 $\mathrm{ml}$ and $2000 \mathrm{ml}$ of seawater, respectively, are $880 \mathrm{C} ; 890 \mathrm{C}$ and 900 . The more the temperature 
in the basin space the greater the production of fresh water (distillate) during the research process.

Overall, the average value produced by the design of a combination of solar panels with transparent glass every day is $128 \mathrm{ml} /$ day, the time required is approximately 3 hours and the average heat generated is $890 \mathrm{C}$. while the average intensity of daylight from $687 \mathrm{~W} / \mathrm{m} 2$ to 713 $\mathrm{W} / \mathrm{m} 2$. The results of testing the tool in the treatment of $1000 \mathrm{ml}$ obtained $98 \mathrm{ml}$ of fresh water; $1500 \mathrm{ml}$ treatment obtained $120 \mathrm{ml}$ fresh water and $2000 \mathrm{ml}$ treatment obtained $165 \mathrm{ml}$ fresh water. These data are data on the volume of water entering and the volume of water that has been distilled for 9 days of testing equipment. In addition to recording the volume of water produced from the device, temperature distribution was also recorded in this study. For the analysis of tool work after examining the performance of the tool from calculated efficiencies, efficiency has a range of $8.0 \%-9.8 \%$.

\section{Conclusions and Suggestions}

\subsection{Conclusion}

Based on the results of calculations and research data that have been done in the previous chapter, some conclusions can be drawn as follows:

1. Within 1 day a device with a type of solar panel combination with transparent glass with a water reservoir size made of aluminum plate with an area of $530 \mathrm{~mm}$ x $430 \mathrm{~mm}$ can produce fresh water with a maximum volume of $127.66 \mathrm{ml}$.

2. Performance on tools designed with a combination of solar panels (photo voltaic) with transparent glass is still relatively low in terms of efficiency which has only reached $9.8 \%$ at its maximum.

3. At the time of the evaporation process starting at 11:00 until 14:00 hours, while the temperature that occurs in the sea water reservoirs between $880 \mathrm{C}-900 \mathrm{C}$.

5.2. Suggestion

After conducting this research, the authors suggest:

a. The design of the tools in the study was not good enough due to the low performance of the equipment, it is necessary to do further research to find out and modify the tool to be able to increase the performance and production of fresh water (distillate yield).

b. As a confounding factor in this study will affect the value of the performance of the tool, then in further research needs to be controlled to get better results.

\section{References}

[1] Effendi, 2003, Water quality for the treatment of living environment biological resources, Bogor. 
[2] Kupang City Central Statistics Agency, 2013, Kupang City Health Profile, Statistics Indonesia, Kupang.

[3] Pabiban, D., Namas, M, and Sarifudin, K. 2016. Parabolic Type Solar Distillation System Model to Reduce Sea Water Salinity Levels. Competitive Grant Research Report. Kupang State Polytechnic, Kupang.

[4] Hasanah, Fatyya (2016). Solar-based decelination to produce fresh water, University of Indonesia, Depok

[5] Aba, L., 2007, Surface Radiation Absorber Surface Characteristics of Solar Still and Its Application as a Distillation Tool for Sea Water into Freshwater, Science Journal of Mathematics and Natural Sciences, 13 (3), 201-205.

[6] Sarmadji Asep, USA, 2008, photovoltaic as a solar power plant, Jakarta.

[7] Irianto, A., 2003, Probiotic Aquaculture, Gadjah Mada University Press, Jogjakarta.

[8] Hidayat, R.R., 2011, Design of Salt and Freshwater Separation Equipment Using Solar Energy, Thesis, Bogor Agricultural University, Bogor.

[9] Budiana, I.G.M.N. and Neolaka, Y., 2008, Basics of Separation, Nusa Cendana University, Kupang.

[10] Kadir Abdul, 1993. Types of distillation, introduction to Suryono, Jakarta.

[11] Lakitan, B., 2002, Fundamentals of Climatology, PT Raja Grafindo Persada, Jakarta.

[12] Hidayat Rahmat, 2013. Definition and Function of the Battery (battery). Yogyakarta.

[13] Zulhan, F, .2011 ,. Design and build a solar electric chrge controller controller, Makassar.

[14] Demastuti Anya. 1997. "Solar Power Plants". Discourse 